\title{
A Real-Time PCR Assay for Detection and Quantification of Verticillium dahliae in Spinach Seed
}

\author{
Dechassa Duressa, Gilda Rauscher, Steven T. Koike, Beiquan Mou, Ryan J. Hayes, Karunakaran Maruthachalam, \\ Krishna V. Subbarao, and Steven J. Klosterman
}

First, second, fourth, fifth, and eighth authors: United States Department of Agriculture-Agricultural Research Service, 1636 E. Alisal St., Salinas, CA; third author: University of California Cooperative Extension, Salinas; and sixth and seventh authors: University of California, Davis, 1636 E. Alisal St., Salinas.

Current address of G. Rauscher: Pioneer Hi-Bred-DuPont Agricultural Biotechnology, Wilmington, DE.

Accepted for publication 26 December 2011.

\begin{abstract}
Duressa, D., Rauscher, G., Koike, S. T., Mou, B., Hayes, R. J., Maruthachalam, K., Subbarao, K. V., and Klosterman, S. J. 2012. A realtime PCR assay for detection and quantification of Verticillium dahliae in spinach seed. Phytopathology 102:443-451.

Verticillium dahliae is a soilborne fungus that causes Verticillium wilt on multiple crops in central coastal California. Although spinach crops grown in this region for fresh and processing commercial production do not display Verticillium wilt symptoms, spinach seeds produced in the United States or Europe are commonly infected with V. dahliae. Planting of the infected seed increases the soil inoculum density and may introduce exotic strains that contribute to Verticillium wilt epidemics on lettuce and other crops grown in rotation with spinach. A sensitive, rapid, and reliable method for quantification of $V$. dahliae in spinach seed may help identify highly infected lots, curtail their planting, and minimize the

spread of exotic strains via spinach seed. In this study, a quantitative realtime polymerase chain reaction (qPCR) assay was optimized and employed for detection and quantification of $V$. dahliae in spinach germplasm and 15 commercial spinach seed lots. The assay used a previously reported $V$. dahliae-specific primer pair (VertBt-F and VertBt-R) and an analytical mill for grinding tough spinach seed for DNA extraction. The assay enabled reliable quantification of $V$. dahliae in spinach seed, with a sensitivity limit of $\approx 1$ infected seed per 100 ( $1.3 \%$ infection in a seed lot). The quantification was highly reproducible between replicate samples of a seed lot and in different real-time PCR instruments. When tested on commercial seed lots, a pathogen DNA content corresponding to a quantification cycle value of $\geq 31$ corresponded with a percent seed infection of $\leq 1.3 \%$. The assay is useful in qualitatively assessing seed lots for $V$. dahliae infection levels, and the results of the assay can be helpful to guide decisions on whether to apply seed treatments.
\end{abstract}

Verticillium wilt, caused by the soilborne fungus Verticillium dahliae, is an economically important disease on a diverse range of crops worldwide $(4,36,40)$. The fungus has a broad host range (4) and survives for years in the soil as microsclerotia. The microsclerotia can be dispersed via farm equipment, soil, and water (25). These features make the control of Verticillium wilt exceedingly difficult once established in a cropping system and, often, expensive soil fumigation is the only control measure available. As effective fumigants, such as methyl bromide, become unavailable for use, disease pressure from this pathogen will increase further. Of additional concern is the dispersal of the pathogen over long distances to new cropping systems, especially because $V$. dahliae can also be seedborne in weeds and crops $(11,45)$.

Spinach seed production only occurs in areas with long-daylength summers to induce flowering, as in northern Europe, the

Corresponding author: S. J. Klosterman

E-mail address: Steve.Klosterman@ars.usda.gov

* The $\boldsymbol{e}$-Xtra logo stands for "electronic extra" and indicates that the online version contains one supplemental figure.

Mention of trade names or commercial products in this publication is solely for the purpose of providing specific information and does not imply recommendation or endorsement by the United States Department of Agriculture (USDA). USDA is an equal opportunity provider and employer.

http://dx.doi.org/10.1094/PHYTO-10-11-0280

This article is in the public domain and not copyrightable. It may be freely reprinted with customary crediting of the source. The American Phytopathological Society, 2012.
U.S. Pacific Northwest, and New Zealand (11). Spinach seeds produced in Europe and the United States are almost invariably infected with $V$. dahliae (11). V. dahliae is clearly localized inside the spinach seed, as revealed by laser-scanning confocal microscopy analyses of spinach seed colonized by a green fluorescent protein-tagged strain of $V$. dahliae (K. Maruthachalam, S. J. Klosterman, A. Anchieta, B. Mou, and K. Subbarao; unpublished data). Interestingly, Verticillium wilt symptoms on spinach are only apparent after bolting (seed stem elongation) (11). Therefore, due the short duration between planting and harvest (as few as 4 weeks), fresh and processing spinach crops do not show wilt symptoms (11). The crop residue that is returned to soil nevertheless harbors the pathogen inoculum that potentially remains in soils that are later planted to lettuce or other crops grown in rotation with spinach. Infected seeds may also introduce exotic strains of $V$. dahliae to new areas of crop production that could be consequential if the introduced genotypes are more aggressive and add to the genetic variability of the pathogen in the recipient areas.

Verticillium wilt was first reported on lettuce in the central coastal region of California in 1995 (43), although the disease was problematic on strawberry and other crops in the region decades prior to that discovery. Since the mid-1990s, Verticillium wilt on lettuce has spread throughout the central coastal California production region. Yield losses in lettuce crops due to $V$. dahliae of up to $100 \%$ have been reported $(43,45)$. The increase in the incidence of the disease on lettuce coincided chronologically with changes in spinach cropping practices, including a trend toward year-around spinach production, an increase in acreage devoted to spinach, and a higher plant density of spinach 
per unit area (2). Because the majority of the U.S. lettuce and fresh spinach is produced in the central coastal region of California, the industry is potentially under long-term threat of $V$. dahliae imported to the region via spinach seeds produced in Europe and the U.S. Pacific Northwest.

Now that the threat posed by seedborne $V$. dahliae is well established, avoidance of planting seed lots with infection levels above a designated threshold is likely to slow the spread of $V$. dahliae via spinach seed. Currently, Mexico requires that imported seed have $<10 \%$ (threshold) infection with $V$. dahliae (21). For avoidance to be effective, timely and accurate knowledge of seed infection levels is required. The conventional NP-10 plating assay, in addition to a widely used blotter assay (11), have been useful to assess the level of seed infected with $V$. dahliae (41). Although these assays can provide a clear view of numbers of infected seed per lot, there are also limitations associated with the administration of these assays. First, the NP-10 plate assay or blotter assay take $\approx 2$ weeks to complete, which makes the plate assays unwieldy for testing a large number of seed lots in a reasonable time frame. Second, these assays do not easily distinguish between $V$. dahliae and closely related species, such as $V$. tricorpus, which can occur on a seed sample. The ideal assay for quantifying $V$. dahliae in commercial seed lots would be accurate, timely, and specific. A quantitative real-time polymerase chain reaction (qPCR)-based quantification of pathogens is a rapid, reliable, and ultrasensitive method and hence, has become the preferred technological platform for detection and quantification of plant pathogens in seed and environmental samples $(7,13$, 22,27).

Harnessing the power of qPCR technology for the purpose of pathogen quantification requires developing pathogen-specific DNA primers and a reliable assay protocol $(9,10,14,32,44)$. Primers for qualitative conventional PCR analysis of $V$. dahliae in plant and soil samples have been previously reported $(23,26,29)$. Atallah et al. (1) characterized a qPCR primer pair (VertBt-F and VertBt-R) derived from the single copy $\beta$-tubulin gene that could readily be adapted for quantification of $V$. dahliae in spinach seed. The specificity of this primer set for the amplification of a 115-bp amplicon of $V$. dahliae was confirmed against a range of other fungi and Verticillium spp. (1). However, the recent finding that $V$. longisporum is actually a hybrid fungus, containing a copy of $V$. dahliae DNA sequences in addition to a separate genomic complement (19), could potentially complicate the use of the VertBt primers for species-specific detection. Nevertheless, $V$. longisporum is a pathogen specific to cruciferous plants $(12,18$, 42 ) and, thus, an association of $V$. longisporum with spinach seed is not expected.
The objectives of this study were to (i) optimize a qPCR assay for the quantification of $V$. dahliae in spinach seed, (ii) determine whether a threshold real-time PCR quantification cycle $(\mathrm{Cq})$ value can be correlated with the percentage of seed infected in commercial seed lots for use as a guide for whether to apply seed treatments or in regulatory decisions, and (iii) determine whether V. longisporum is detectable in commercial spinach seed lots.

\section{MATERIALS AND METHODS}

Seed sample collection and NP-10 plate assays. Fifteen seed lots were obtained from U.S. and European commercial spinach seed producers (Table 1) between December 2009 and May 2011. All seed were stored at $-20^{\circ} \mathrm{C}$ until use for qPCR sampling. Upon receipt, subsamples of these seed lots were evaluated for percentage of seed infected with $V$. dahliae on NP-10 plates (41). Briefly, seed were surface sterilized with $1.2 \%$ commercial bleach for $1 \mathrm{~min}$, triple-rinsed with sterile water, and subsequently air dried under a laminar flow hood on sterile paper towels. At least 400 seeds from each seed lot were plated, in replicates of 100 or 200 seeds for each lot. Plates were incubated at $25^{\circ} \mathrm{C}$ in the dark for 10 days and the percentage of infected seed was recorded (Table 1).

Seed samples from the United States Department of Agriculture, North Central Regional Plant Introduction Station (NCRPIS) spinach germplasm collection (Table 2) were surface sterilized as above and plated on NP-10 medium. However, due to limitations in the numbers of seed available for each accession, only 20 seeds were plated per accession. In addition, seed of this collection were evaluated after 14 days of incubation for the presence of $V$. dahliae and $V$. tricorpus, based upon colony morphology on the NP-10 plates. Unlike $V$. dahliae, which produces concentric rings of microsclerotia on NP-10 plates, $V$. tricorpus produces a diffuse arrangement of microsclerotia (picture not shown).

Seed lot subsampling and DNA extraction. The qPCR assay was conducted on three replicate seed samples, with each sample containing 1,000 seeds taken from the individual seed lots. The large numbers of seed per lot were sampled to provide an adequate sample to minimize the effect of seed-to-seed variation in pathogen load per seed. The seed samples were ground for $\approx 45 \mathrm{~s}$ to a fine powder using an IKA A10 analytical grinding mill (IKA Laboratory, Germany). Between samples, the stainless steel grinding chamber of the mill was washed with deionized water and rinsed with $70 \%$ ethanol.

DNA extractions were conducted from 200-mg fractions of 1,000 ground seeds $(\approx 10 \mathrm{~g})$ using a FastDNA kit following the manufacturer's protocol (MP Biomedicals, Solon, OH), except

TABLE 1. Quantification of Verticillium dahliae using NP-10 plate and quantitative real-time polymerase chain reaction (qPCR) assays in 15 commercial spinach seed lots

\begin{tabular}{|c|c|c|c|c|}
\hline \multirow[b]{2}{*}{ Seed lot } & \multicolumn{2}{|c|}{ NP10 plate assay } & \multicolumn{2}{|c|}{ qPCR assay ${ }^{\mathrm{a}}$} \\
\hline & Infected seed/seed tested & Seed infected with $V$. dahliae (\%) & Pathogen copy number & $\mathrm{Cq}$ value \\
\hline 1 & $341 / 400$ & 85 & $544.68 \pm 94.97$ & $26.20 \pm 0.26$ \\
\hline 2 & $307 / 400$ & 77 & $2141.19 \pm 728.40$ & $25.38 \pm 0.20$ \\
\hline 4 & $289 / 400$ & 72 & $638.01 \pm 186.33$ & $26.32 \pm 0.53$ \\
\hline 5 & $272 / 400$ & 68 & $301.17 \pm 120.47$ & $27.78 \pm 0.68$ \\
\hline 6 & $385 / 600$ & 64 & $666.32 \pm 185.07$ & $25.94 \pm 0.48$ \\
\hline 10 & $63 / 400$ & 16 & $844.28 \pm 165.10$ & $26.09 \pm 0.31$ \\
\hline 11 & $63 / 400$ & 16 & $255.98 \pm 47.16$ & $27.20 \pm 0.28$ \\
\hline 12 & $23 / 400$ & 5.8 & $56.94 \pm 8.02$ & $29.60 \pm 0.23$ \\
\hline 13 & $5 / 400$ & 1.3 & $29.72 \pm 4.87$ & $31.11 \pm 0.50$ \\
\hline 14 & $4 / 600$ & 0.7 & $1.46 \pm 0.45$ & $35.81 \pm 0.81$ \\
\hline 15 & $1 / 400$ & 0.3 & $4.72 \pm 1.32$ & $34.44 \pm 0.54$ \\
\hline
\end{tabular}

${ }^{\text {a }}$ Mean \pm standard deviation. 
that the IKA A10 mill was used for sample homogenization in place of the FastPrep Instrument. DNA extracts were further purified with AMPure magnetic beads and a SPRI 96-Ring Magnet Plate (Agencourt, Beverly, MA) to cleanse DNA of potential PCR inhibitors. DNA concentration was measured using a Qubit fluorometer and Quant-iT dsDNA BR Assay Kit (Invitrogen, Carlsbad, CA). All DNA samples were diluted to $1 \mathrm{ng} / \mu \mathrm{l}$ in nuclease-free water and $5 \mu \mathrm{l}$ of the diluted DNA was used for qPCR. To determine the number of DNA extractions needed per seed lot to accurately determine $V$. dahliae concentration, preliminary $\mathrm{qPCR}$ data were generated from $\leq 18$ extractions of three seed lots. Using the pooled standard-deviation from this data, the $99 \%$ margin of error was calculated as the standard error $\times t$ value using hypothetical numbers of DNA extractions of 2 to 31 . Using the approach, six DNA extractions should result in a Cq margin of error of 0.82. Based on this result, six 200-mg fractions of the ground seed were taken from each of three samples (1,000 seeds/ sample) for DNA extraction and qPCR for all subsequent experiments.

For the NCRPIS seed samples (Table 2), DNA was extracted from 4 seeds/accession using a MoBio PowerPlant Extraction kit (MO BIO Laboratories, Inc., San Diego) and a micropestle for grinding the seed in a microfuge tube. Seed were soaked in a $1.5-\mathrm{ml}$ microcentrifuge tube with $550 \mu \mathrm{l}$ of PowerPlant Bead Solution for $1 \mathrm{~h}$ and crushed with a micropestle, and the resulting homogenate was transferred to PowerPlant Bead Tubes for DNA purification following the procedures in the PowerPlant DNA Isolation Kit. DNA concentration was measured as described above. AMPure DNA extract (50 ng) was then used in qPCR analysis.

qPCR assay. Quantitative PCR was carried out in the LightCycler 480 model II (Roche Diagnostics, Indianapolis, IN). Reactions were prepared in 96-well plates (USA Scientific, Orlando, FL) in total reaction volumes of $20 \mu \mathrm{l}$ containing $10 \mu \mathrm{l}$ of 1× IQ SYBR Green Supermix (Bio-Rad, Hercules, CA), $0.4 \mu \mathrm{l}$ of forward (VertBt-F 5'-AACAACAGTC CGATGGATAATTC$3^{\prime}$ ) and reverse (VertBt-R 5'-GTACCGGGCTCGAGATCG-3') primers (1) at concentrations of $200 \mathrm{nM}$ each, $5 \mu \mathrm{l}$ of template DNA (1 or $5 \mathrm{ng}$ total), and $4.6 \mu \mathrm{l}$ of nuclease-free water. Each DNA sample was loaded in triplicate in a 96-well plate. The temperature profile for qPCR was as follows: $95^{\circ} \mathrm{C}$ for a 5 -min denaturation step; followed by 40 cycles of amplification at $95^{\circ} \mathrm{C}$ for $10 \mathrm{~s}$ and $65^{\circ} \mathrm{C}$ for $35 \mathrm{~s}$; and melt curve analysis of heating to $95^{\circ} \mathrm{C}$, cooling to $65^{\circ} \mathrm{C}$ for $1 \mathrm{~min}$, and heating to $97^{\circ} \mathrm{C}$ at a rate of $1^{\circ} \mathrm{C} / 5 \mathrm{~s}$. The spinach actin was used as a reference gene (GenBank accession JN987183) and was amplified in each sample using primer pair SO385-F, 5'-TCCGTGCAGGTATTGTG CTG-3' and SO489-R, 5'-AGCAAGGTCGAGACGAAGG-3' at a concentration of $300 \mathrm{nM}$ under the same qPCR cycling conditions as described above. Known standards for quantification of the $V$. dahliae $\beta$-tubulin gene were prepared. To prepare the standard, the $\beta$-tubulin gene fragment was PCR amplified from DNA extracted from naturally infected seed of the NCRPIS spinach accession $165560 \mathrm{C}$ using the VertBt primer pair and cloned into a PCR4.0TOPO vector (Invitrogen). The quantity of DNA from $V$. dahliae in the seed samples was then estimated using copynumber-based, five-point $(500,000,50,000,5,000,500$, and 50 copies) internal standard curves constructed by serial dilution of linearized plasmid vector DNA carrying the $\beta$-tubulin gene fragment from $V$. dahliae. The absolute quantification module of the LightCycler software was used to determine $\mathrm{Cq}$ and pathogen copy number. The threshold $\mathrm{Cq}$ value was manually adjusted to 1.0 for all qPCR experiments to enable run-to-run comparisons. DNA melt peaks were analyzed at the end of each run to ensure specificity of amplification of the $\beta$-tubulin gene fragment.

For the NCRPIS seed samples, qPCR analysis was conducted on a Bio-Rad ICycler real-time PCR system (Bio-Rad) using the same VertBt and actin primers and identical PCR conditions, with the exception that the annealing temperature was adjusted to $63^{\circ} \mathrm{C}$ and the adjustment to $50 \mathrm{ng}$ of DNA template. DNA melt peaks were analyzed at the end of each run to ensure specificity of amplification of the $\beta$-tubulin gene fragment. Additionally, the 115 -bp product of the $\beta$-tubulin gene was amplified from DNA template derived from accession NSL184380 (Table 2) and sequenced directly for verification of the correct product (matching with $100 \%$ sequence identity to the corresponding 115-bp sequence from $V$. dahliae, GenBank accession DQ840621).

Inter-instrumental reproducibility of the qPCR assay. Seed samples with artificial infection levels of $0.7,2,5,10,25,50$, and $64 \%$ were created by blending seed lot 6 (64\% infection) and seed lot $14(0.7 \%$ infection), hereafter referred to as seed samples with artificial infection gradient. The samples were then assayed independently on the Roche LightCycler 480 II and the Bio-Rad ICycler real-time PCR instruments under the same reaction and cycling conditions (annealing temperature of $65^{\circ} \mathrm{C}$ ) to examine the inter-instrumental reproducibility of the qPCR assay.

Effect of DNA template clean-up and evaluation of PCR inhibitors. All of the qPCR assays described were conducted using AMPure purified DNA, because PCR inhibitors are commonly found in seed tissue samples $(8,15)$. To evaluate the results in the absence of this template clean-up step, AMPure magnetic bead-purified DNA and unpurified DNA were assayed by qPCR to determine the necessity of incorporating a DNA template clean-up step in the qPCR assay protocol. This was done using the seed samples with artificial infection gradient created by blending seed lots 6 and 14. For PCR inhibition tests, sensitivity of detection of plasmid DNA containing 50 copies of $V$. dahliae $\beta$-tubulin gene in water (pure plasmid DNA) was compared with detection in the background of $5 \mathrm{ng}$ of AMPure (or unpurified) seed DNA from seed lot 14 (0.7\% infection). The assumption made was that any difference between $\mathrm{Cq}$ values of the spiked seed DNA samples and pure plasmid DNA would be due to the presence of PCR inhibitors in the seed DNA samples.

Survey of spinach seed lots for contamination with $\mathrm{V}$. longisporum. To determine whether $V$. longisporum was present on the

TABLE 2. Comparison of quantitative real-time polymerase chain reaction (qPCR) and NP-10 plate assays for detection of Verticillium dahliae in spinach germplasm seed collections

\begin{tabular}{lrrl}
\hline Accession & $\begin{array}{c}\beta \text {-Tubulin copy } \\
\text { number (qPCR) }\end{array}$ & $\begin{array}{c}\text { Average Cq } \\
(\text { qPCR })\end{array}$ & $\begin{array}{c}\text { NP-10 plate } \\
\text { assayb }^{\mathrm{b}}\end{array}$ \\
\hline PI 171859 & 11 & 34.08 & $\mathrm{~N}$ \\
PI 254565 & 22 & 33.31 & $\mathrm{~N}$ \\
PI 174388 & 15 & 34.20 & $\mathrm{~N}$ \\
PI 339546 & 101 & 30.97 & $\mathrm{~N}$ \\
PI 604791 & 3,780 & 28.41 & $\mathrm{~N}$ \\
PI 175930 & 228 & 30.05 & V. dahliae \\
PI 358259 & 6 & 35.22 & V. tricorpus \\
PI 4661 & 1,330 & 27.71 & V. tricorpus \\
PI 176771 & 151 & 31.18 & $\mathrm{~N}$ \\
PI 339259 & 154 & 30.42 & Not determined \\
PI 6082 & 97 & 31.02 & V. tricorpus \\
PI 179507 & 46 & 32.31 & $\mathrm{~N}$ \\
PI 361127 & 2 & 36.59 & V. dahliae \\
NSL 6093 & 358 & 29.66 & V. dahliae \\
PI 200882 & 29 & 32.88 & $\mathrm{~N}$ \\
PI 368825 & 3,250 & 29.03 & V. dahliae \\
NSL 28216 & 983 & 28.01 & V. dahliae \\
PI 206473 & 232 & 29.88 & $\mathrm{~N}$ \\
PI 370602 & 144 & 30.90 & V. tricorpus \\
NSL 28218 & 138 & 30.64 & V. dahliae \\
PI 220121 & 6,750 & 25.39 & V. dahliae \\
PI 370602 & 634 & 28.58 & V. tricorpus \\
NSL 184380 & 126,000 & NA & V. tricorpus \\
PI 445784 & 0 & & \\
\hline
\end{tabular}

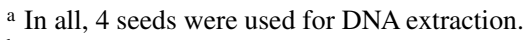

${ }^{\mathrm{b}}$ In all, 20 seeds were plated and scored. $\mathrm{N}=V$. dahliae not detected.

c NA $=$ not amplified. 
spinach seed lots, 15 commercial seed lots were screened using the $V$. longisporum-specific primer pair 5'-TCTCCTCTC TACGAGAACGA-3' and 5'-CACTTTCTAAGTATCCTTCCTAT$3^{\prime}$ (42) by conventional PCR. PCR cycling parameters included an initial denaturation at $94^{\circ} \mathrm{C}$ for $2 \mathrm{~min}$; followed by 30 cycles of $94^{\circ} \mathrm{C}$ for $2 \mathrm{~min}, 48^{\circ} \mathrm{C}$ for $2 \mathrm{~min}$, and $72^{\circ} \mathrm{C}$ for $3 \mathrm{~min}$; and a final extension at $72^{\circ} \mathrm{C}$ for $10 \mathrm{~min}$. PCR amplifications on the commercial seed lots were carried out in a total reaction volume of $50 \mu \mathrm{l}$, containing $1 \mu \mathrm{l}$ of the FastDNA extracted seed DNA template $(25 \mathrm{ng})$ from the commercial spinach seed lots, $15 \mathrm{pmol}$ of each primer, and GoTaq PCR Mastermix (Promega Corp., Madison, WI). To obtain a positive control for PCR amplification of $V$. longisporum DNA in the background of spinach seed DNA, a 1- $\mu$ l dilution containing $25 \mathrm{ng}$ of DNA template from $V$. longisporum, strain Bob70 (38), was mixed into $1 \mu \mathrm{l}$ of $25 \mathrm{ng}$ of DNA extracted from seed lot 10 (Table 1), and $1 \mu \mathrm{l}$ of this template mixture was used in PCR. In addition, $25 \mathrm{ng}$ of DNA template from $V$. dahliae, strain VdLs.16 (38) was used as a negative control. DNA templates from strains VdLs.16 and Bob70 were prepared using a standard bead beat procedure for fungal DNA isolation (39).

Measurements of the lengths of conidia from isolates of commercial seed lots also were compared with those of $V$. longisporum, to examine whether $V$. longisporum was present in the seed lots. The lengths of conidia for $V$. dahliae and $V$. longisporum were expected to be $\approx 4.4$ and $7.9 \mu \mathrm{m}$, respectively, based on a previous report of the lengths of conidia of short-conidia and long-conidia strains of Verticillium spp. (24). Fungal isolates from seed lots 1, 4, 6, 10, and 11 from diverse geographic locations (United States and Europe) were obtained by culturing 15 seeds/ seed lot on NP-10 plates following the procedure for NP-10 plate assay described above. Subsequently, the lengths of 4,700 conidia (7 to 10 isolates/seed lot and 100 conidia/isolate) were measured using an Olympus BX60 microscope fitted with a DP70 digital camera and DP manager software (Olympus America, NY), and compared with the lengths of conidia of $V$. longisporum isolate Bob70.

Data analysis. Linear regression analysis was used to evaluate the relationship between percent seed infection and pathogen DNA quantity in spinach seed.

\section{RESULTS}

Optimization of seed grinding procedure and template DNA for qPCR assay. The IKA grinder was effective for rapidly grinding 1,000 seeds/sample, enabling the timely processing of samples. Further, by increasing the template DNA amount used for qPCR from 1 to $5 \mathrm{ng}$, we were able to detect DNA from $V$. dahliae in the spinach seed background with sufficient sensitivity. Using $1 \mathrm{ng}$ of template DNA extracted from three replicates of 1,000 seeds from an artificial seed infection of $2 \%$, no amplification was recorded in 24 of 63 reactions (38\%) (data not shown). In contrast, amplification was recorded in all reactions $(100 \%)$ when the spinach DNA template of $5 \mathrm{ng}$ was applied for qPCR on an artificial seed infection level of $2 \%$ (data not shown). Subsequently, the spinach DNA template concentration of $5 \mathrm{ng}$ was used in the qPCR testing of all commercial seed lots.

Correlation between percent seed infection and pathogen DNA quantity. The relationship between pathogen DNA copy number and percent seed infection was linear and highly significant $\left(R^{2}=0.99, P=0.0001\right)$ when assessed on seed samples with an artificial infection gradient of 0.7 to $64 \%$ (Fig. 1A). However, when the relationship between pathogen copy number and percent seed infection was examined in 15 naturally infected seed lots, the correlation was numerically small, though statistically significant $\left(R^{2}=0.32, P=0.027\right)$. Cube root transformation of pathogen copy number and percent seed infection data improved the correlation $\left(R^{2}=0.66, P=0.0002\right)$ (Fig. 1B). Despite the reduced correlation in 15 naturally infected seed lots compared with seed samples with artificially infection gradient, the overall trend was that pathogen DNA quantity decreased as percent seed infection decreased. An important observation in this regard was that a pathogen DNA quantity corresponding to a $\mathrm{Cq}$ value of $\geq 31$ correlated with a percent seed infection of $\leq 1.3 \%$ (Table 1) in the naturally infected seed lots.

Sensitivity and reproducibility of the qPCR assay in naturally infected seed lots. The qPCR assay was highly sensitive and reproducible between replicate samples of a seed lot. qPCR assays of the 15 naturally infected seed lots with infection levels determined by NP-10 plate assays of 0.3 to $85 \%$ showed detection of $V$. dahliae at the $1.3 \%$ infection level for seed lot 13

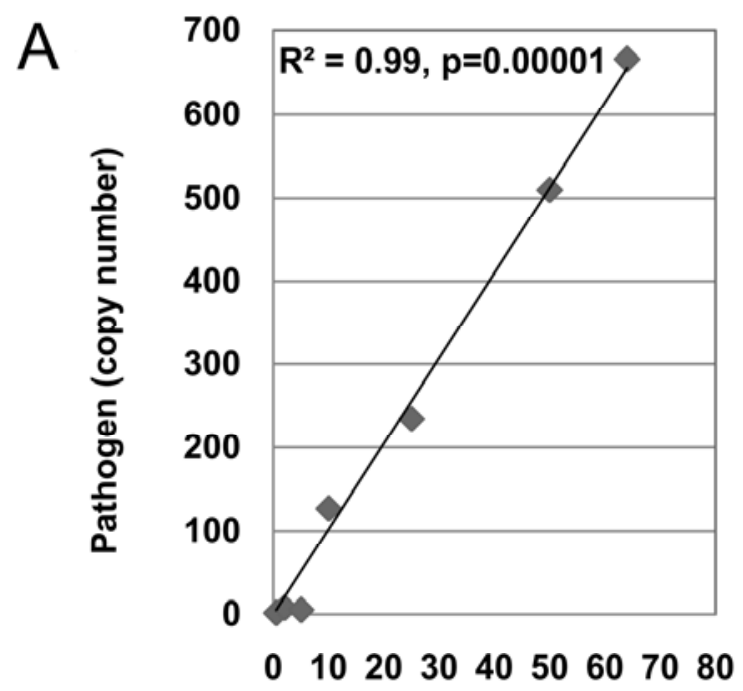

Percent seed infection
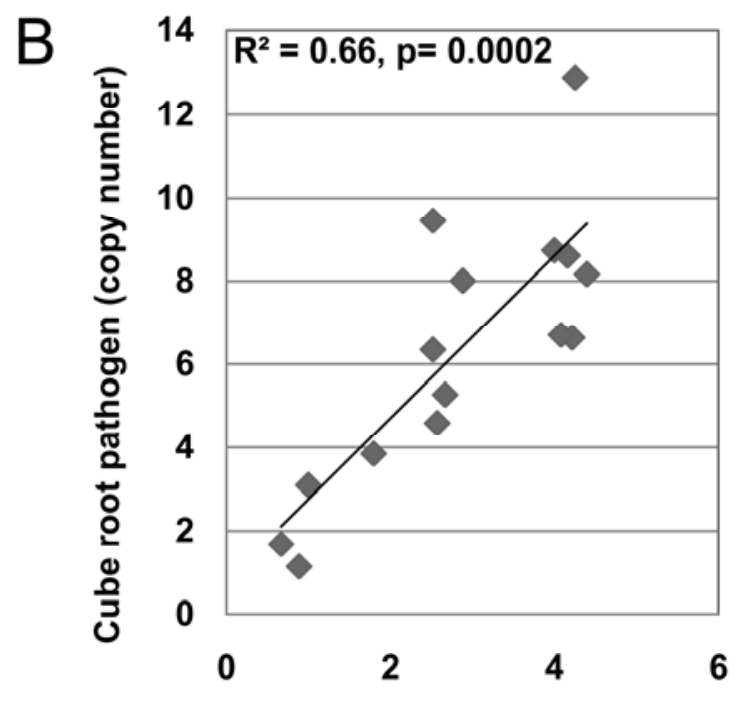

Cube root percent seed infection

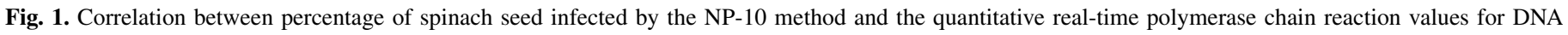

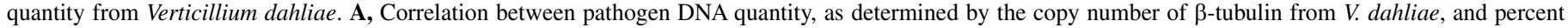

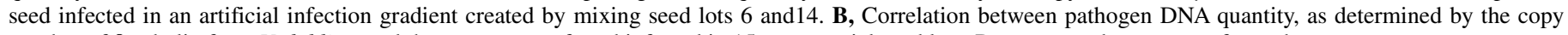
number of $\beta$-tubulin from $V$. dahliae, and the percentage of seed infected in 15 commercial seed lots. Data were cube root transformed. 
(Table 1), which translates to a sensitivity limit of $\approx 1$ infected seed per 100. At infection levels below this, detection was possible but was not reproducible $(\mathrm{Cq}$ values were recorded for all replicate samples for seed lot 13 but not for seed lots 14 and $15)$. The assay was also highly reproducible between replicate samples of a seed lot using $5 \mathrm{ng}$ of DNA template, as revealed by the low standard deviation associated with the Cq values (Table 1).

Reproducibility on two different qPCR machines. Comparative testing of seed samples with artificial infection gradients of 0.7 to $64 \%$ on the Roche LighterCycler and the Bio-Rad ICycler real-time PCR instruments under similar PCR conditions produced nearly identical results (Fig. 2A), showing a high interinstrumental reproducibility of the test. Correlation between pathogen copy numbers quantified with the Roche LightCycler and the Bio-Rad ICycler was highly significant $\left(R^{2}=0.99, P=\right.$ 6.84E-7) (Fig. 2B).

Germplasm screening. Twenty-four germplasm accessions obtained from the NCRPIS spinach germplasm collection were tested for $V$. dahliae infection. Because low numbers of seed were available for each of the accessions, the IKA A10 grinding mill was not employed for sample homogenization in these experiments. In spite of the low number of seed assessed for the germplasm accessions, the qPCR assay enabled detection of $V$. dahliae in 23 of 24 of the spinach germplasm accessions, whereas the NP-10 plate detected $V$. dahliae in 7 of 23 of the accessions examined (Table 2). In 16 of the accessions, the NP-10 plate assay test revealed negative results for the detection of $V$. dahliae whereas, in 7 of the accessions, V. tricorpus was detected.

Effect of DNA purification on the sensitivity of the qPCR test. We evaluated the effect of DNA template clean-up intended to remove potential PCR inhibitors purified with DNA on the sensitivity of the qPCR. DNA purification slightly increased (decreased $\mathrm{Cq}$ by $\approx 0.5$ ) the sensitivity of detection of $V$. dahliae in spinach seed in the 2 to $64 \%$ infection range in seed samples with artificial infection gradient (Table 3). However, the effect of PCR inhibitors was evident when testing purified $\beta$-tubulin template spiked in DNA from seed. Comparison of $\mathrm{Cq}$ values obtained using purified plasmid DNA corresponding to 50 copies of the $V$. dahliae $\beta$-tubulin gene and $\mathrm{Cq}$ values of the same plasmid amplified in the background of $5 \mathrm{ng}$ of AMPure (or unpurified) spinach seed DNA showed a decrease in sensitivity of the qPCR when seed DNA is present. Cq values were $30.20 \pm 0.44$ for pure plasmid DNA, $32.98 \pm 0.93$ for plasmid DNA amplified in the background of AMPure seed DNA, and $35.67 \pm 1.05$ for plasmid DNA amplified in the background of unpurified seed DNA.

Results from the amplification of spinach actin gene as an external control in the different seed lots revealed similar $\mathrm{Cq}$ values across all seed lots (Table 4), suggesting amplification with similar efficiencies in the different seed lots and the absence of any significant variation in PCR inhibitors in spinach seed DNA template obtained with the FastDNA kit and AMPure purification.

Survey of $V$. longisporum contamination of the seed lots. The 115 -bp $\beta$-tubulin amplicon was detectable by PCR using the VertBt primers from both $V$. dahliae isolates and the $V$. longisporum isolate, Bob70 (data not shown). Therefore, extracts from the 15 commercial seed lots used in this study were screened with

TABLE 3. Effect of additional DNA purification on the sensitivity of quantitative real-time polymerase chain reaction (qPCR) as reflected in quantification cycle $(\mathrm{Cq})$ in seed samples with artificial infection gradients created by mixing seed lots 6 and 14

\begin{tabular}{lcccc}
\hline $\begin{array}{l}\text { Seed } \\
\text { infection (\%) }\end{array}$ & $\begin{array}{c}\mathrm{Cq} \\
\text { (purified DNA) }^{\mathrm{a}}\end{array}$ & $\mathrm{SD}^{\mathrm{b}}$ & $\begin{array}{c}\mathrm{Cq} \\
\text { (unpurified DNA) }^{\mathrm{c}}\end{array}$ & $\mathrm{SD}$ \\
\hline 0.7 & 35.66 & 0.95 & 34.70 & 1.51 \\
2 & 32.26 & 0.49 & 32.86 & 0.64 \\
5 & 33.02 & 0.20 & 33.67 & 0.83 \\
10 & 29.02 & 0.19 & 29.61 & 0.28 \\
25 & 27.65 & 0.22 & 28.28 & 0.13 \\
50 & 26.43 & 0.30 & 27.64 & 0.32 \\
64 & 26.03 & 0.26 & 26.86 & 0.20 \\
\hline
\end{tabular}

${ }^{a}$ FastDNA kit extracted DNA purified with an AMPure kit; average of 18 replicate assays.

${ }^{\mathrm{b}} \mathrm{SD}=$ standard deviation

${ }^{c}$ FastDNA kit extracted DNA; average of 18 replicate assays.

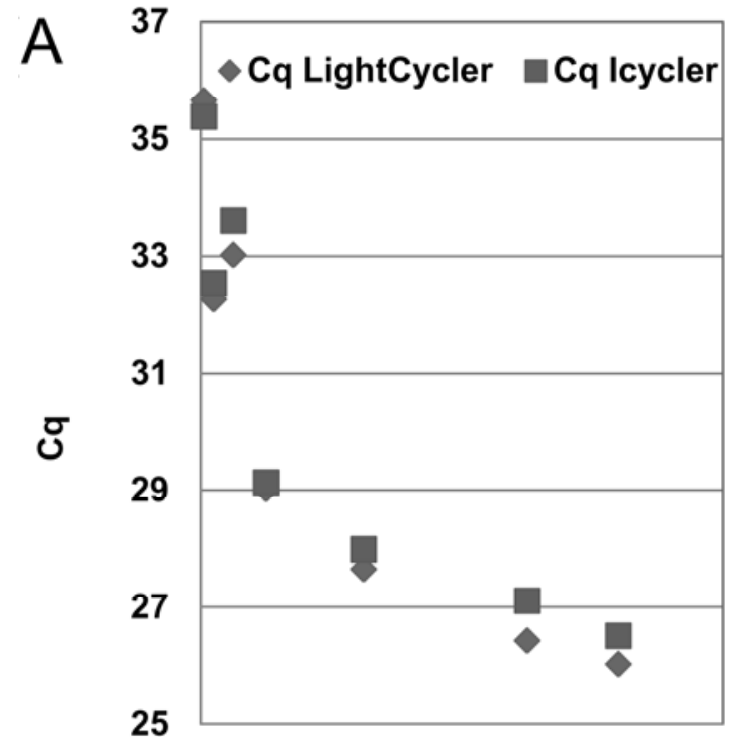

$\begin{array}{llllllllll}0 & 10 & 20 & 30 & 40 & 50 & 60 & 70 & 80\end{array}$

Percent seed infection

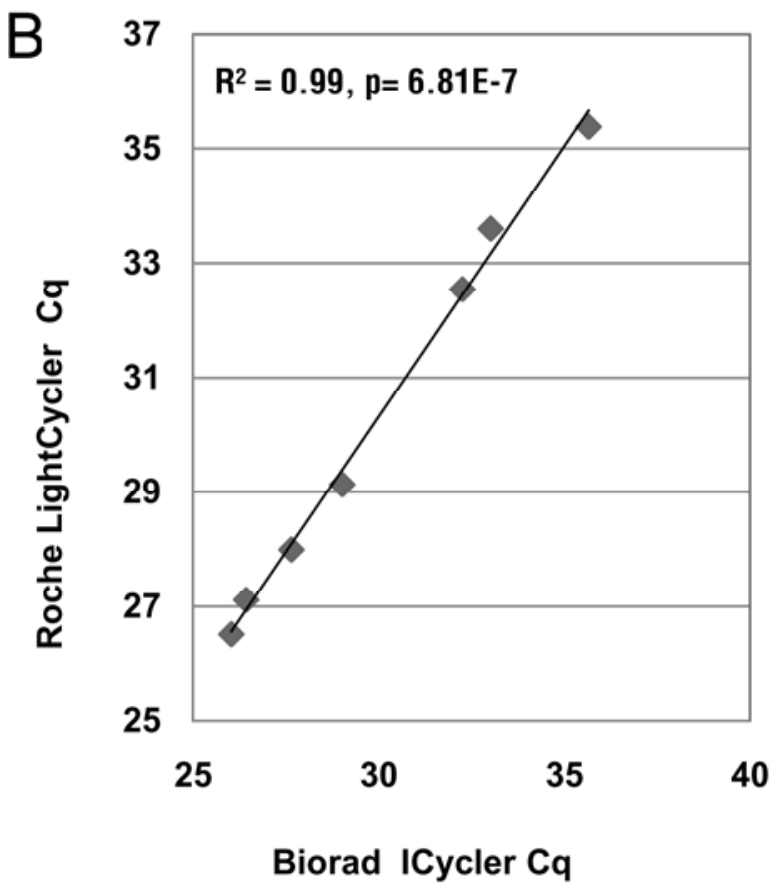

Fig. 2. Interinstrumental reproducibility of the quantitative real-time polymerase chain reaction (PCR) assay for quantification of Verticillium dahliae in spinach seed with artificial infection levels. A, Scatter plot of the average threshold real-time PCR quantification cycle (Cq) readings by the Roche LightCycler and BioRad ICycler real-time PCR instruments on seed samples with varying artificial infection levels. B, Correlation between Cq values measured by LightCycler and ICycler real-time PCR instruments. 
a $V$. longisporum-specific primer pair (42). The 340-bp amplicon unique to $V$. longisporum was amplified from DNA obtained from $V$. longisporum and in spinach seed DNA that was spiked with $V$. longisporum (Fig. 3). However, the amplicon of the expected size of $340 \mathrm{bp}$ was not amplified from any of the spinach seed lots examined in this study (Fig. 3). Further, measurements of 4,700 conidia of the multiple individual fungal isolates obtained from five seed lots revealed an average conidia length of $3.91 \pm$ $0.80 \mu \mathrm{m}$ compared with a conidia length of $8.75 \pm 1.55 \mu \mathrm{m}$ for V. longisporum isolate Bob70 (Supplemental Figure 1).

\section{DISCUSSION}

The discovery of the widespread contamination of commercial spinach seed lots with $V$. dahliae (11) prompted a need to develop a rapid, sensitive, and specific seed health testing method that may help curb the spread of the fungus. The conventional NP-10 plate assay for $V$. dahliae is unwieldy for rapid testing of the large number of seed lots produced by commercial seed companies. Additionally, the conventional NP-10 plate assay may not always easily differentiate $V$. dahliae from other fungi in seed samples. In this study, an alternative qPCR assay for pathogen quantification was developed using primers derived from the single copy $\beta$ tubulin gene (VertBt primers) of $V$. dahliae (1) and evaluated using spinach seed lots from growing regions in Europe and the United States.

Spinach seed sampling for $\mathrm{qPCR}$ required an alternate sample homogenization procedure because dry spinach seed is exceed-

TABLE 4. Average quantification cycle $(\mathrm{Cq})$ values obtained from quantitative real-time polymerase chain reaction ( $\mathrm{qPCR}$ ) analyses of a spinach actin gene used as a control in 15 seed lots

\begin{tabular}{lccc}
\hline Seed lot & Cq actin & SD $^{\mathrm{a}}$ & Number of tests \\
\hline 1 & 23.51 & 0.67 & 54 \\
2 & 22.96 & 0.54 & 90 \\
3 & 22.39 & 0.40 & 18 \\
4 & 22.93 & 0.46 & 36 \\
5 & 22.86 & 0.75 & 18 \\
6 & 23.42 & 0.31 & 126 \\
7 & 22.65 & 0.45 & 18 \\
8 & 22.44 & 0.23 & 18 \\
9 & 23.08 & 0.14 & 18 \\
10 & 23.02 & 0.25 & 18 \\
11 & 22.93 & 0.16 & 18 \\
12 & 22.98 & 0.25 & 18 \\
13 & 23.06 & 0.15 & 18 \\
14 & 23.16 & 0.24 & 18 \\
15 & 22.70 & 0.12 & \\
\hline
\end{tabular}

a $\mathrm{SD}=$ standard deviation. ingly difficult to grind with a mortar and pestle method commonly used for sample homogenization for DNA extraction. Even wet spinach seed are difficult to grind using a mortar and pestle, because of the thick, hard, outer fruit wall present in spinach seed. Further, the numbers of seed that could be partially homogenized with a mortar and pestle or micropestle technique are too small to adequately represent the voluminous lots from which the seed are drawn. The initial approach of sample preparation for DNA extraction and subsequent qPCR was based on homogenization of four seeds using a micropestle in a microcentrifuge tube. As such, the mortar and pestle grinding technique was not optimal for obtaining the necessary homogeneity and yield of the extracted DNA (5). Seed homogenization with a micropestle procedure was laborious for the operator and the sample size was deemed inadequate as a representative sample of the population for quantitative analyses. Therefore, we optimized the grinding protocol by adopting the use of IKA A10 grinding mill, which is capable of grinding large seed samples with remarkable speed $(\approx 45 \mathrm{~s})$, and upscaled the sample size used for DNA extraction to 1,000 seeds/ sample.

Another requirement of DNA preparation for a qPCR assay is elimination or reduction of PCR inhibitors which are commonly found in DNA extracts from seed $(8,15,28,32,37)$. PCR inhibitors in DNA extracts may increase false negative readings, and could detrimentally affect a qPCR test result by reducing amplification efficiency. A trace amount of inhibitor is sufficient to obscure pathogen detection at the lower end of the dynamic range of qPCR. DNA purification with commercial kits and dilution of the DNA extract have proven effective in minimizing the effect of inhibitors on PCR reactions $(5,17,32)$. Treatment of DNA with polyvinylrrolidone has also been reported to greatly improve the sensitivity of PCR-based tests by reducing the effect of inhibitors $(30,31,35,46)$. In developing the qPCR assay reported herein, DNA was extracted with a FastDNA kit and subsequently purified with AMPure magnetic beads to eliminate or reduce the amount of potential PCR inhibitors. Nonetheless, we found that addition of the AMPure purification step had only a slight effect on the sensitivity of the qPCR test (decreasing the $\mathrm{Cq}$ value by $\approx 0.5$ in the 2 to $64 \%$ seed infection range). Further, a valid quantitative DNA analysis such as a qPCR assay requires that the DNA template be of homogeneous quality for the samples being compared $(5,20)$. As an indirect measure for homogeneity and integrity of the DNA extracts from the different seed lots, amplification of a spinach actin gene was used as a control in all DNA amplifications. The actin amplification efficiencies, as deduced from $\mathrm{Cq}$ values, were similar among all seed lots, confirming that the DNA extracts were of similar quality and that variation in DNA purity should not affect the results obtained. Dilution of the template DNA may further reduce the impact of PCR inhibitors.

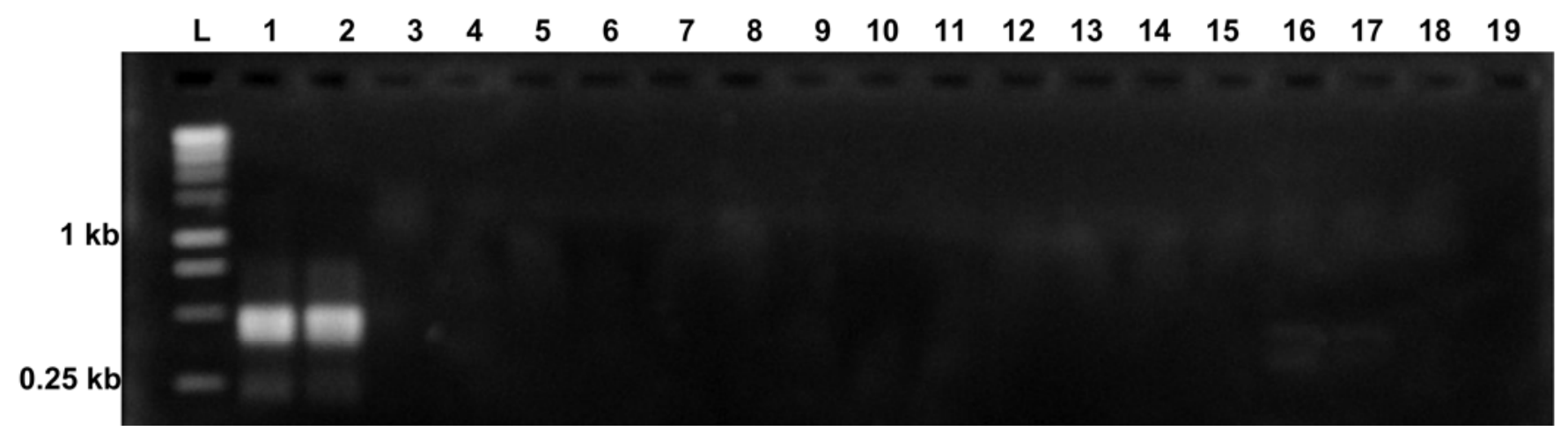

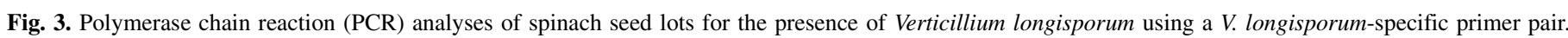

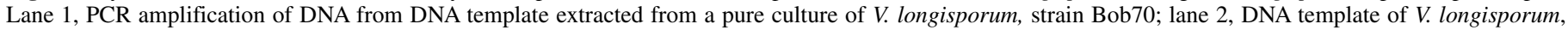

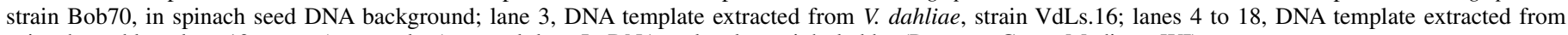
spinach seed lots; lane 19, water (no template) control; lane L, DNA molecular weight ladder (Promega Corp., Madison, WI). 
In this study, the initial attempt to quantify $V$. dahliae by qPCR using $1 \mathrm{ng}$ of template DNA was not successful because the results were not reproducible. Hence, we subsequently increased the template DNA to $5 \mathrm{ng}$ and were able to detect and quantify $V$. dahliae with sufficient sensitivity.

For a diagnostic assay to be successfully employed, a high level of sensitivity and specificity is required $(6,9,31)$. The VertBt primers detect as little as $148 \mathrm{fg}$ (equivalent of five nuclei) of $V$. dahliae DNA in the background of potato tissue as indicated by Atallah et al. (1), based upon one $V$. dahliae genome in one nucleus $\approx 28 \mathrm{fg}(42)$. In spinach seed extracts, we found that the VertBt primers reliably quantified $V$. dahliae at a sensitivity limit of 1 infected seed per 100 ( $\approx 29$ nuclei or $812 \mathrm{fg}$ of DNA), which is well below the current Mexican government importation standard for $V$. dahliae-infected spinach seed of $\leq 10 \%$ (21). At limits of seed infection $<1.3 \%$, detection was possible but quantification was not reproducible because there were cases in which the test was negative in some replicates of $<1.3 \%$ infection levels. Compared with the standard NP-10 plate assay, the analytical and diagnostic sensitivity of the qPCR assay described herein is high. Diagnostic assays of 24 spinach germplasm accessions for seed infection with $V$. dahliae using the qPCR assay and NP-10 plate assay showed that the qPCR assay detected infected seed with $100 \%$ accuracy (23 of 23) whereas the NP-10 plate assay detection accuracy was only $29 \%$ (7 of 24). Similarly high diagnostic sensitivity of PCR over plate assays for detection of $V$. dahliae has been previously reported $(1,23,26,29)$. These results clearly show the greater diagnostic sensitivity and specificity of the qPCR assay over the NP-10 plate assay.

The recent discovery that $V$. longisporum is a hybrid species sharing genomic sequence in common with $V$. dahliae (19) prompted examination of possible cross-amplification of $V$. longisporum. Even though $V$. longisporum is a crucifer-specific pathogen and not expected to be associated with spinach seed $(12,18$, 42), V. longisporum may nevertheless be a surface contaminant on spinach seed, and empirical proof is desirable for the satisfaction of the end users of the assay. Therefore, we screened the commercial seed lots with a $V$. longisporum-specific primer pair (42). In addition, conidia length measurements (4,700 conidia) of fungal isolates from five seed lots did not indicate the presence of $V$. longisporum. The conidia length differences between $V$. dahliae and $V$. longisporum reported in this study $(3.91 \pm 0.80 \mu \mathrm{m}$ $V$. dahliae versus $8.75 \pm 1.55 \mu \mathrm{m} V$. longisporum) and those reported by Karapapa et al. (24) $(4.4 \pm 0.23 \mu \mathrm{m} V$. dahliae versus $7.9 \pm 0.08 \mathrm{~V}$. longisporum) were similar. In summary, both molecular evidence and that obtained from conidia size measurements indicated that $V$. longisporum was not present on the spinach seed lots examined and, thus, did not interfere with the accuracy of the qPCR assay.

Repeatability or reproducibility of test results is another key consideration in seed health test assay development $(3,34)$. The qPCR assay developed here is reproducible between replicate samples of a seed lot and real-time PCR instruments. The Cq standard deviation for the experiments of the naturally infected seed lots was 0.05 to 0.81 , which is within limits of minor random fluctuations in instrumental measurement. Assays of seed samples with artificial infection gradient of 0.7 to $64 \%$ on both the BioRad ICycler and Roche Diagnostics LightCycler real-time PCR instruments yielded nearly identical measurements of pathogen DNA from spinach seed samples. These two real-time PCR instruments are in widespread use, enabling applicability of the test in many research laboratories.

A challenging aspect in developing a PCR-based pathogen assay is finding a significant correlation between seed pathogen DNA quantity as measured by qPCR and seed pathogen incidence as determined by plate assays. We and others have demonstrated that these measures are highly correlated in seed samples with artificial infection gradient created by mixing infected seed and uninfected seed (or those with a very low level of infection), or in seed samples artificially inoculated with an incremental pathogen dose $(8,17,33)$. However, in naturally infected seed lots, the correlation between seed pathogen DNA content and percentage of seed infected is often low or not evident $(8,13,22)$, with few exceptions $(3,13)$. Such incongruity is not due to flaws in DNA purification or qPCR parameters. Rather, the major causes for this incongruity may be (i) seed lot to seed lot variability in the amount of pathogen among individual seed in a seed lot or (ii) the ability of qPCR to quantify both live and dead fungi. If one seed lot contains only a few infected seed with a high pathogen load per seed, compared with another seed lot with a high number of infected seed at low pathogen load per individual infected seed, qPCR quantification may give similar results for the two seed lots but NP-10 plate would record a higher percentage infection in the latter seed lot. Similarly, more fungi would be detectable using the NP-10 plate assay in seed lots with more live fungi, regardless of the total fungal biomass in the seed lot. A qPCR assay based on a sampling scheme of one seed per DNA extraction could provide a robust assessment of the relationship between seed pathogen DNA content and percent seed infection $(8,13)$, although the technologies to make this approach commercially feasible do not currently exist. Increasing the amount of seed per DNA extraction might also be a sound alternative to narrow the discrepancy between plate and qPCR assays. In developing the present assay, 1,000 seeds were used per DNA extraction. The large number of seed per DNA extraction was undoubtedly useful in decreasing inter-replicate variations. However, even the testing of this high number of seed per sample did not lead to a strong correlation between the percentage of seed infected determined by a plate assay and seed pathogen DNA quantity determined by qPCR in the 15 naturally infected commercial seed lots.

Even though a high correlation between the percentage of seed infected and pathogen DNA quantity is not the main focus of many of the qPCR assays currently available for seed pathogen detection and quantification, the assays provide important qPCR thresholds of practical value. For example, McNeil et al. (33) found that $44 \mathrm{pg}$ of Tilletia caries DNA corresponds to $<1$ conidia/seed of wheat, Bates et al. (3) found that $2.8 \mathrm{pg}$ of Pyrenophora sp. DNA corresponds with $0.3 \%$ barley seed infection, Justesen et al. (22) found that $8.6 \mathrm{pg}$ of Pyrenophora graminea DNA corresponds with $5 \%$ seed infection in a susceptible barley variety, and Guillemette et al. (16) found that $2 \%$ infection of cruciferous seed with Alternaria brassicae corresponds with pathogen DNA quantity equivalent of a $34 \mathrm{Cq}$ value. These examples demonstrate that seed pathogen DNA quantity in conjunction with a regulatory threshold could be a useful guide in making seed treatment and regulatory decisions for plant pathogens. In the present study, even if $\mathrm{Cq}$ was not strongly correlated with percent seed infection from seed lot to seed lot, the overall trend is that as the $\mathrm{Cq}$ value increases the percentage of seed infected decreases. We observed that a $\mathrm{Cq}$ value of $\geq 31$ corresponds with a percent seed infection of $\leq 1.3 \%$ in the 15 naturally infected spinach seed lots. Based on this relationship, the qPCR assay may be applied for seed treatment decisions to limit the migration of $V$. dahliae in spinach seed. Although the correlation between percent seed infection and seed pathogen DNA content was not high for the naturally infected spinach seed lots, the assay also can provide a qualitative measure of infection to narrow down the numbers of seed lots to test for the verification of infection levels. Hence, for seed samples with $\mathrm{Cq}$ values of 29 to 31 (3 of 15 seed lots in this study) (Table 1), the NP-10 plate or blotter assay for the verification of percent seed infection would be advisable.

Bates et al. (3) stipulated that a seed health test should also be sensitive, specific, reliable, and rapid. The assay developed herein is sufficiently sensitive, with a detection limit of 1 infected seed per 100. In addition, the qPCR assay takes a day to complete 
compared with $\approx 2$ weeks required for a conventional NP-10 plate or blotter assay. The use of the IKA analytical grinding mill for sample homogenization represented a key feature of the assay, enabling analyses of an increased number of seed per sample and the enhanced robustness of the assay. The qPCR assay reliably quantified DNA of $V$. dahliae between replicate samples drawn from a seed lot, PCRs, and real-time PCR instruments.

Future improvement of the assay will depend on advances in related technologies such as an automated high-throughput seed grinding system to enable parallel processing of large numbers of samples, and kits specifically designed for purification of DNA from seed tissue. At present, however, it is difficult to conceive of a different seed lot sampling design that may improve the colinearity between percent seed infection determined by the plate assay and pathogen DNA quantity. In the current format, the qPCR assay described herein can be useful to assess the infection levels of $V$. dahliae in spinach seed lots, representing a valuable tool in the management of Verticillium wilt. The qPCR assay also may be useful as a tool to assist in screening spinach germplasm collections for resistance to $V$. dahliae.

\section{ACKNOWLEDGMENTS}

We thank the California Department of Food and Agriculture-Specialty Crop Block Grant and the California Leafy Greens Research Program for funding, A. Anchieta and K. Kammeijer for technical assistance, F. Martin for review of the manuscript, and Z. Atallah and G. Bilodeau for advice.

\section{LITERATURE CITED}

1. Atallah, Z. K., Bae, J., Jansky, S. H., Rouse, D. I., and Stevenson, W. R. 2007. Multiplex real-time quantitative PCR to detect and quantify Verticillium dahliae colonization in potato lines that differ in response to Verticillium wilt. Phytopathology 97:865-872.

2. Atallah, Z. K., Maruthachalam, K., du Toit, L., Koike, S. T., Michael Davis, R., Klosterman, S. J., Hayes, R. J., and Subbarao, K. V. 2010. Population analyses of the vascular plant pathogen Verticillium dahliae detect recombination and transcontinental gene flow. Fungal Genet. Biol. 47:416-422.

3. Bates, J. A., Taylor, E. J. A., Kenyon, D. M., and Thomas, J. E. 2001.The application of real-time PCR to the identification, detection and quantification of Pyrenophora species in barley seed. Mol. Plant Pathol. 2:49-57.

4. Bhat, R. G., and Subbarao, K.V. 1999. Host range specificity in Verticillium dahliae. Phytopathology 89:1218-1225.

5. Brandfass, C., and Karlovsky, P. 2008. Upscaled CTAB-based DNA extraction and real-time PCR assays for Fusarium culmorum and Fusarium graminearum DNA in plant material with reduced sampling error. Int. J. Mol. Sci. 9:2306-2321.

6. Broders, K. D., and Boland, G. J. 2010. Molecular diagnostic assay for detection of the butternut canker pathogen Sirococcus clavigignentijuglandacearum. Plant Dis. 94:952-958.

7. Bustin, S. A., Benes, V., Garson, J. A., Hellemans, J., Huggett, J., Kubista, M., Mueller, R., Nolan, T., Pfaffl, M. W., Shipley, G. L., Vandesompele, J., and Wittwer, C. T. 2009. The MIQE guidelines: Minimum information for publication of quantitative real-time PCR experiments. Clin. Chem. 55:611-622.

8. Chilvers, M. I., du Toit, L. J., Akamatsu, H., and Peever, T. L. 2007. A real-time, quantitative PCR seed assay for Botrytis spp. that cause neck rot of onion. Plant Dis. 91:599-608.

9. Cho, M. S., Kang, M. J., Kim, C. K., Seol, Y.-J., Hahn, J. H., Park, S. C., Hwang, D. J., Ahn, T.-Y., Park, D. H., Lim, C. K., and Park, D. S. 2011. Sensitive and specific detection of Xanthomonas oryzae pv. oryzae by real-time bio-PCR using pathovar-specific primers based on an rhs family gene. Plant Dis. 95:589-594.

10. Diguta, C. F., Rousseaux, S., Weidmann, S., Bretin, N., Vincent, B., Guilloux-Benatier, M., and Alexandre, H. 2010. Development of a qPCR assay for specific quantification of Botrytis cinerea on grapes. FEMS Microbiol. Lett. 313:81-87.

11. du Toit, L. J., Derie, M. L., and Hernandez-Perez, P. 2005. Verticillium wilt in spinach seed production. Plant Dis. 89:4-11.

12. Eynck, C., Koopmann, B., Grunewaldt-Stoecker, G., Karlovsky, P., and von Tiedemann, A. 2007. Differential interactions of Verticillium longisporum and Verticillium dahliae with Brassica napus detected with molecular and histological techniques. Eur. J. Plant Pathol. 118:259-274.
13. Glynn, N. C., and Edwards, S. G. 2010. Evaluation of PCR assays for quantifying seed-borne infection by Fusarium and Microdochium seedling blight pathogens. J. Appl. Microbiol. 108:81-87.

14. Glynn, N. C., Ray, R., Edwards, S. G., Hare, M. C., Parry, D. W., Barnett, C. J., and Beck, J. J. 2007. Quantitative Fusarium spp. and Microdochium spp. PCR assays to evaluate seed treatments for the control of Fusarium seedling blight of wheat. J. Appl. Microbiol. 102:1645-1653.

15. Gudmestad, N. C., Mallik, I., Pasche, J. S., Anderson, N. R., and Kinzer, K. 2009. A real-time PCR assay for the detection of Clavibacter michiganensis subsp. sepedonicus based on the cellulase A gene sequence. Plant Dis. 93:649-659.

16. Guillemette, T., Iacomi-Vasilescu, B. A., and Simoneau, P. 2004. Conventional and real-time PCR-based assay for detecting pathogenic Alternaria brassicae in cruciferous seed. Plant Dis. 88:490-496.

17. Ha, Y., Fessehaie, A., Ling, K. S., Wechter, W. P., Keinath, A. P., and Walcott, R. R. 2009. Simultaneous detection of Acidovorax avenae subsp. citrulli and Didymella bryoniae in cucurbit seed lots using magnetic capture hybridization and real-time polymerase chain reaction. Phytopathology 99:666-678.

18. Heale, J. B., and Karapapa, V. K. 1999. The Verticillium threat to Canada's major oilseed crop: Canola. Can. J. Plant Pathol. 21:1-7.

19. Inderbitzin, P., Davis, R. M., Bostock, R. M., and Subbarao, K. V. 2011. The ascomycete Verticillium longisporum is a hybrid and a plant pathogen with an expanded host range. PLoS ONE 6:18260.

20. Ioos, R., Fourrier, C. 1., Iancu, G., and Gordon, T. R. 2009. Sensitive detection of Fusarium circinatum in pine seed by combining an enrichment procedure with a real-time polymerase chain reaction using duallabeled probe chemistry. Phytopathology 99:582-590.

21. IPC. 2003. International phytosanitary certificate no. 4051. Phytosanitary federal law of the Mexican United States.

22. Justesen, A., Hansen, H., and Pinnschmidt, H. 2008. Quantification of Pyrenophora graminea in barley seed using real-time PCR. Eur. J. Plant Pathol. 122:253-263.

23. Karajeh, M. R., and Masoud, S. A. 2006. Molecular detection of Verticillium dahliae Kleb. in asymptomatic olive trees. J. Phytopathol. 154:496-499.

24. Karapapa, V. K., Bainbridge, B. W., and Heale, J. B. 1997. Morphological and molecular characterization of Verticillium longisporum comb. nov. pathogenic to oilseed rape. Mycol. Res. 101:1281-1294.

25. Klosterman, S. J., Atallah, Z. K., Vallad, G. E., and Subbarao, K. V. 2009. Diversity, pathogenicity, and management of Verticillium species. Annu. Rev. Phytopathol. 47:39-62.

26. Li, K. N., Rouse, D. I., Eyestone, E. J., and German, T. L. 1999. The generation of specific DNA primers using random amplified polymorphic DNA and its application to Verticillium dahliae. Mycol. Res. 103:13611368.

27. Lievens, B., Brouwer, M., Vanachter, A. C. R. C., Cammue, B. P. A., and Thomma, B. P. H. J. 2006. Real-time PCR for detection and quantification of fungal and oomycete tomato pathogens in plant and soil samples. Plant Sci. 171:155-165.

28. Ma, Z., and Michailides, T. J. 2007. Approaches for eliminating PCR inhibitors and designing PCR primers for the detection of phytopathogenic fungi. Crop Prot. 26:145-161.

29. Mahuku, G., and Platt, H. 2002. Quantifying Verticillium dahliae in soils collected from potato fields using a competitive PCR assay. Am. J. Potato Res. 79:107-117.

30. Malvick, D. K., and Grunden, E. 2005. Isolation of fungal DNA from plant tissues and removal of DNA amplification inhibitors. Mol. Ecol. Notes 5:958-960.

31. Malvick, D. K., and Impullitti, A. E. 2007. Detection and quantification of Phialophora gregata in soybean and soil samples with a quantitative realtime PCR assay. Plant Dis. 91:736-742.

32. Mbofung, G. C. Y., and Pryor, B. M. 2010. A PCR-based assay for detection of Fusarium oxysporum f. sp. lactucae in lettuce seed. Plant Dis. 94:860-866.

33. McNeil, M., Roberts, A. M. I., Cockerell, V., and Mulholland, V. 2004. Real-time PCR assay for quantification of Tilletia caries contamination of UK wheat seed. Plant Pathol. 53:741-750.

34. Montes-Borrego, M., MuÃ-Ledesma, F. J., Jim, R. M., and Landa, B. B. Real-time PCR quantification of Peronospora arborescens, the opium poppy downy mildew pathogen, in seed stocks and symptomless infected plants. Plant Dis. 95:143-152.

35. Okubara, P. A., Schroeder, K. L., and Paulitz, T. C. 2008. Identification and quantification of Rhizoctonia solani and Rhizoctonia oryzae using real-time polymerase chain reaction. Phytopathology 98:837-847.

36. Pegg, B., and Brady, G. 2002. Verticillium Wilts. CABI Publishing, New York.

37. Pryor, B. M., and Gilbertson, R. L. 2001. A PCR-based assay for detection of Alternaria radicina on carrot seed. Plant Dis. 85:18-23.

38. Qin, Q. M., Vallad, G. E., Wu, B. M., and Subbarao, K. V. 2006. Phylogenetic analyses of phytopathogenic isolates of Verticillium spp. 
Phytopathology 96:582-592.

39. Radford, A. 1991. Methods in Yeast Genetics: A Laboratory Course Manual. M. Rose, F. Winston, and P. Hieter, eds. Cold Spring Harbor Laboratory, Cold Spring Harbor, NY.

40. Rampersad, S. N. 2010. Verticillium dahliae (Kleb.) infecting pumpkin seed. J. Phytopathol. 158:329-333.

41. Sorensen, L. H., Schneider, A. T., and Davis, J. R. 1991. Influence of sodium polygalacturonate sources and improved recovery of Verticillium species from soil. Phytopathology 81:1347.

42. Steventon, L. A., Fahleson, J., Hu, Q., and Dixelius, C. 2002. Identification of the causal agent of Verticillium wilt of winter oilseed rape in Sweden, V. longisporum. Mycol. Res. 106:570-578.

43. Subbarao, K. V., Hubbard, J. C. Greathead, A. S., and Spencer, G. A.
1997. Verticillium wilt. Pages 26-27 in: Compendium of Lettuce Diseases. R. M. Davis, K. V. Subbarao, R. N. Raid, and E. A. Kurtz, eds. The American Phytopathological Society, St. Paul, MN.

44. Tooley, P. W., Carras, M. M., Sechler, A., and Rajasab, A. H. 2010. Realtime PCR detection of sorghum ergot pathogens Claviceps africana, Claviceps sorghi and Claviceps sorghicola. J. Phytopathol. 158:698-704.

45. Vallad, G. E., Bhat, R. G., Koike, S. T., Ryder, E. J., and Subbarao, K. V. 2005. Weedborne reservoirs and seed transmission of Verticillium dahliae in lettuce. Plant Dis. 89:317-324.

46. Van Gent-Pelzer, M. P. E., Van Brouwershaven, I. R., Kox, L. F. F., and Bonants, P. J. M. 2007. A TaqMan PCR method for routine diagnosis of the quarantine fungus Guignardia citricarpa on citrus fruit. J. Phytopathol. 155:357-363. 